\title{
Alapjogi bíráskodás különleges helyzetekben: a strasbourgi bíróság releváns esetjoga
}

\author{
különleges helyzetek - emberi jogok nemzetközi védelme - Emberi Jogok \\ Európai Bírósága - alkotmányos demokrácia - derogáció
}

Az alkotmányos demokráciák életében békeidőben is megfigyelhető bizonyos alkalmazkodás az egyes különleges helyzetek kezelése érdekében, akkor is, ha egyébként a különleges helyzetek jó része kezelhető a hagyományos jogrend által biztosított alkotmányos mechanizmusok alkalmazásával. İgy például a különbözö jogkorlátozási tesztek vagy a korlátozás garanciáit jelentő alkotmányos eljárási mechanizmusok hivatottak biztosítani a jogállamiságot. Témám szempontjából ugyanakkor a kérdés az, hogy vajon olyan különleges helyzetekben (mint például terrortámadás, terrorfenyegetettség, súlyos természeti katasztrófa vagy ipari szerencsétlenség), amikor a jogkorlátozás hagyományos garanciarendszerének alkalmazása a hatékony védekezést és az állam, a társadalom biztonságát veszélyeztetné, milyen mértékü jogkorlátozás tekinthetö szükségesnek és indokoltnak. A kivételes állapoti jogkorlátozásokkal kapcsolatos legfontosabb kérdés, hogy ha a különleges helyzet elhárítása érdekében az állam egyes alapvető jogok, illetve az alkotmányos demokrácia kontrollfunkciói ideiglenes korlátozásának vagy felfüggesztésének eszközével él, akkor ez nem eredményezi-e végső soron magának az alkotmányos demokráciának a végét? ${ }^{1}$ Azt követően ugyanis, hogy az állam részben feladott valamennyit az alkotmányos demokrácia értékeiből, vajon egy esetleges reparáció elegendő-e ahhoz, hogy ismételten ugyanarról a rendszerröl beszélhessünk? Az egyes jogkorlátozásokkal kapcsolatos, alapjogi konfliktusokkal terhelt jogviták esetén az alapjogi bíráskodás szerepe kiemelten fontos, igaz, az alapjogok korlátozására nemcsak jogalkalmazás, hanem jogalkotás útján is van lehetőség. ${ }^{2}$ Bár az alapjogok korlátozásának és az ezzel kapcsolatos bírói jogalkalmazásnak az egyik fontos esetköre az alapjogok más alapjogok védelme érdekében történő korlátozása, jelen tanulmány kizárólag a köz érdekében történő alapjogkorlátozás esetével foglalkozik. ${ }^{3}$

* Dr. Mészáros Gábor egyetemi tanársegéd, Pécsi Tudományegyetem Állam- és Jogtudományi Kar, meszaros.gabor@ajk.pte.hu.

1 LAZAR, Nomi Claire: States of Emergency in Liberal Democracies. Cambridge University Press, New York, 2009, 1-18.

2 PozsÁr-Szentmikıósy Zoltán: Alapjogok mérlegen - Az általános alapjogi tesztek dogmatikája. HVG-ORAC, Budapest, 2016, 18.

3 Az alapjogok korlátozásának általános jellemzőiről lásd részletesen PozsÁR-SzentMIKLósY: i. m., 17-25. 
A kivételes állapoti jogkorlátozás és a bírói alapjogi mérlegelés fontos aspektusa az Emberi Jogok Európai Bíróságának (a továbbiakban: EJEB vagy Bíróság) vonatkozó gyakorlata. Az EJEB gyakorlatának ilyen szempontból történő tematikus vizsgálata azért is indokolt, mert az Emberi Jogok Európai Egyezményének (a továbbiakban: Egyezmény) hatálya szélesebb az Európai Unió tagállamainak körénél. Az Egyezmény által létrehozott rendszer nem más, mint egy olyan emberi jogi rezsim, amelyben az EJEB bírósági felülvizsgálat alá veheti a tagállami jogalkotást és jogalkalmazást, mindezt pedig a kérelmező azon állítása alapján, miszerint a tagállami magatartás sérti az Egyezményben foglalt emberi jogait. ${ }^{4} \mathrm{~A}$ Bíróság releváns gyakorlata jórészt az Egyezmény 15. cikke által meghatározott, amelynek értelmében bizonyos körülmények fennállása esetén lehetőség van az Egyezmény alkalmazásának felfüggesztésére. Írásomban először az Egyezménnyel kapcsolatos alapvető elvekkel, majd a derogáció kérdésével fogok általánosságban foglalkozni. Ezt követően ismertetem a "nemzet létét fenyegető más rendkívüli állapot” fogalmához kapcsolódó, illetöleg a mérlegelési jogkör doktrínájával kapcsolatos alapvető kérdéseket. Végül az Egyezmény hatályának részletes bemutatását végzem el.

Az EJEB hatásköre ugyan nem terjed ki a részes államok bírósági döntéseinek megsemmisítésére, mégis az egyéni jogvédelem leghatékonyabb európai bíróságaként tarthatjuk számon, hiszen jogosult az Egyezményben és a kiegészítő jegyzökönyvekben foglalt jogok megsértésének megállapitására és emiatt kártérítés megítélésére, így valamennyi szerződő állam belső jogrendszerétől és joggyakorlatától elvárható közös minimumot biztosít az Egyezmény szerinti jogokkal kapcsolatban. ${ }^{5}$ Megállapítható az is, hogy az EJEB a társadalmi körülmények változására figyelemmel újból és újból újraértelmezi a védett jogok tartalmát, azok korlátait, ezáltal pedig a fejlettebb jogrendszerek megoldásainak európai minimummá történő elfogadásában is jelentős szerepet vállal. ${ }^{6}$ Magyarország 1993-ban törvényben hirdette ki az Egyezményt és annak több kiegészítő jegyzőkönyvét, amelyek belső jogunk részévé váltak, ${ }^{7}$ majd a későbbiekben ugyancsak törvény hirdette ki a tizenegyedik jegyzökönyvet $1998-b a n,{ }^{8}$ a tizennegyedik jegyzökönyvet $2005-$ ben $^{9}$ vagy a tizen-

4 Helfer, R. Laurence: Overlegalizing Human Rights: International Relations Theory and the Commonwealth Caribbean Backlash against Human Rights Regimes. Columbia Law Review, 2002/7, 1832. Meg kell jegyezni ugyanakkor, hogy az írás szempontjából releváns derogációs ügyekkel kapcsolatos eddigi gyakorlatban a kérelmezők nem csupán saját jogaik védelme érdekében fordulhatnak (fordulhattak) az EJEB-hez, hanem ismerjük az államközi panaszokkal kapcsolatos eljárást is.

5 Az Egyezmény elfogadásáról és a kialakult eljárásrendről lásd részletesen vAN DıJk, Pieter-vAN Hoof, J. H. Godefridus: Theory and Practice of the European Convention on Human Rights. Kluwer Law International, Martinus Nijhoff Publishers, the Hague,1998, 74-76, valamint KARDos Gábor: Az emberi jogokat védő nemzetközi jogi intézmények. In: Halmai Gábor-Tóth Gábor Attila (szerk.): Emberi jogok. Osiris, Budapest, 2003, 155-168.

6 Kardos: i. m., 158-159.

7 Az emberi jogok és az alapvető szabadságok védelméről szóló, Rómában, 1950. november 4-én kelt egyezmény és az ahhoz tartozó nyolc kiegészítő jegyzőkönyv kihirdetéséről szóló 1993. évi XXXI. törvény.

8 Az emberi jogok és alapvető szabadságok védelméről szóló egyezmény tizenegyedik jegyzőkönyvének kihirdetéséröl szóló 1998. évi XLII. törvény.

9 Az emberi jogok és alapvető szabadságok védelméről szóló egyezmény tizennegyedik jegyzőkönyvének kihirdetéséről szóló 2005. évi CXXIV. törvény. 
ötödik jegyzőkönyvet 2015-ben. ${ }^{10} \mathrm{Az}$ EJEB gyakorlatának elemzése így a hazai jogirodalom számára is értékes, kiemelt jelentőségủ az alapjogok korlátozása terén.

\section{A derogációról általában}

Az Egyezmény 15. cikk (1) bekezdése értelmében háború vagy a nemzet létét fenyegető más rendkívüli állapot esetén „,bármely Magas Szerződő Fél a jelen Egyezményben meghatározott kötelezettségeitöl eltérő intézkedéseket tehet a helyzet szükségessége által feltétlenül megkivánt mértékben, feltéve, hogy az ilyen intézkedések nem ellentétesek egyéb nemzetközi jogi kötelezettségeivel". A rendelkezés derogációs szabály, amely bizonyos korlátok között lehetővé teszi az Egyezményben foglaltaktól való eltérést. Az Egyezmény 15. cikke nemcsak a jogok felfüggesztésének lehetőségét biztosítja, hanem részletesen tartalmazza a felfüggeszthetö jogok alóli kivételeket [(2) bekezdés], valamint egy látszólag szigorú eljárási szabályt is [(3) bekezdés], amely lehetóvé teszi az EJEB számára, hogy megvizsgálja a tagállamok által a derogáció időtartama alatt tett jogkorlátozó intézkedéseket.

A derogációs vagy eltérést engedő rendelkezések általánosságban olyan jogkorlátozást lehetővé tevő intézmények, amelyeket az egyes szerződő államok kivételes állapot esetén használhatnak, de ennek egyik alapvető feltétele, hogy a tagállam (vagy annak képviselője) a különleges helyzet fennállását bejelentse. ${ }^{11}$ Ezzel összefüggésben a kivételes hatalomgyakorlásának két formája ismert. ${ }^{12} \mathrm{Az}$ egyik megoldás egy speciális eljárásjogi szabályrendszer, amely a kivételes állapot fenntartását és ellenőrzését is biztosítja. A másik pedig a rendes jogrendtöl különálló autonóm rendszert képzel el. ${ }^{13} \mathrm{~A}$ derogáció végső soron egy harmadik alternatívát jelent, amely ugyanakkor az elsöhöz áll közel azzal, hogy egy nemzetközi emberi jogi szerződésben (vagy alkotmányban) foglaltakkal egyébként ellentétes intézkedéseket tesz lehetővé azáltal, hogy az egyébként egyezménysértő (vagy alkotmánysértö) intézkedéseket a kivételes állapotra történő hivatkozás legitimálja korlátozott ideig. ${ }^{14}$ A derogáció alkalmazhatóságának feltétele, hogy szükséges egy államok felett álló szervezet, amely felülvizsgálja nemcsak a derogáció végrehajtását, hanem ellenőrzi az annak keretében érintett egyéni jogkorlátozásokat is, hiszen a nemzetközi jog önmagában, intézményes garanciák nélkül csekély hatást tudna kifejteni. ${ }^{15}$

10 Az emberi jogok és alapvető szabadságok védelméröl szóló egyezmény tizenötödik jegyzőkönyvének kihirdetéséről szóló 2015. évi CLVII. törvény.

11 CowELL, Frederick: Sovereignity and the Question of Derogation: An Analysis of Article 15 of the ECHR and the Absence of a Derogation Clause in the ACHPR. Birckbeck Law Review, 2013/1, 136-137.

12 Neocleous, Mark: The Problem with Normality: Taking Exception to „Permanent Emergency”. Alternatives: Global, Local Political, 2006/2, 191-213.

13 Ackerman, Bruce: The Emergency Constitution. The Yale Law Journal, 2004/5, 1038.

14 Bondzie-Simpson, Ebow: A Critique of the African Charter on Human and Peoples Rights. Harvard Law Journal, 1988, 660, idézi CoweLL: i. m.,137.

15 Grossman, Claudio: A Framework for the Examination of States of Emergency under the American Convention on Human Rights. American University International Law Review Policy, 1986/1, 35. 
Felmerül a kérdés, hogy a különleges helyzettel érintett állam létének megóvása és a társadalom biztonságának érdeke mellett van-e további célja a derogációs rendelkezéseknek? Cowell szerint a derogációs rendelkezések a jogvédelmet szolgáló eszközök. ${ }^{16}$ Ennek fényében egyrészt az emberi jogi egyezményekkel szemben alapvető követelmény bizonyos mértékü rugalmasság, alkalmazkodási készség. Abban az esetben pedig, ha a szabályozás bizonyos abszolút jogokat nevesít, az alapvető jogvédelem további garanciális elemmel bővül. Összességében tehát a derogációs rendelkezés nem pusztán segítség az érintett állam számára, hogy kezelhesse a különleges helyzetet, hanem egyúttal garancia arra is, hogy az alapvető jogok védelmének szintje a veszély elmúltával helyreáll.

Fontos hangsúlyozni, hogy a derogáció nem egyenlő az érintett jog vagy jogok megszüntetésével. Egyes szerzők szerint, bár a derogációs rendelkezések a kormányzati mozgástér és ezáltal az eltérés lehetőségének biztosítékai, ez mégsem jelenti azt, hogy a joguralom felfüggesztésre kerülne. Sokkal inkább arról van szó, hogy a derogáció a normális állapot és a kivételesség közötti kapcsolatot teremti meg. ${ }^{17}$ Ezzel ellentétes álláspont is megfogalmazódik ugyanakkor, amely szerint a normális-kivételes állapot dichotómia képtelen felismerni és kezelni a permanens kivételes állapotokat, hiszen nem létezik olyan helyzet, amikor a normális és a kivételes állapot egyidejüleg kezelhető lenne.${ }^{18} \mathrm{~A}$ nemzetközi jog mindenesetre nem ismeri a joguralom teljes felfüggesztésének lehetőségét, így a jogi alapelvek a derogáció során is érvényesülnek. ${ }^{19}$

\section{Az Egyezmény 15. cikkének felépítése, mechanizmusa}

Kérdésként merül fel, hogy a tagállamok miért is vetették alá magukat az Egyezmény által megkövetelt felülvizsgálati fórumnak. Ennek elsődleges oka a második világháborúban és annak európai traumájában keresendő, amikor is a legtöbb európai ország vagy a fasizmus szörnyüségei alól éppen megmenekült, vagy pedig a kommunizmus rémével nézett szembe ${ }^{20}$ rosszabb esetben pedig mindkettó érvényesült. Éppen ezért a legtöbb állam az 1950-es évekre eljutott annak az igénynek a megfogalmazásáig, hogy szükséges egy nemzetek felett álló mechanizmus, amely képes garantálni az alkotmányos demokratikus örökséget. ${ }^{21} \mathrm{Az}$ Egyezmény elfogadásával és az EJEB létrehozásával olyan, a mai napig jelentős hatással rendel-

16 Cowell: i. m., 137-143.

17 HIGGINS, Rosalyn: Derogations under Human Rights Treaties. British Yearbook of International Law, 1978/1, 286.

18 Gross, Oren: Once More Unto the Breach: The Systematic Failure of Applying the European Convention on Human Rights to Entrenched Emergencies. Yale Journal of International Law, 1998/2, 455-456.

19 LAUTERPACHT, Hersch: The Function of Law in the International Community. Oxford University Press, Oxford, 2011, 391; idézi LehmanN, Julian M.: Limits to Counter-Terrorism: Comparing Derogation from the International Covenant on Civil and Political Rights and the European Convention on Human Rights. Human Rights Review, 2011/1, 104-105.

20 Cowell: i. m., 143-144.

21 Moravcsik, Andrew: The Origins of Human Rights Regimes Democratic Delegation in Postwar Europe. International Organization, 2000, 231. 
kező rendszer jött létre, amely hatékonyan szolgálta az emberi jogok megőrzését, egyúttal viszont az államok szuverén hatalmának korlátozását eredményezte. Az Egyezmény 15. cikkének hátterében kettős cél mutatható ki: egyrészt egyfajta antitotalitárius igény és ezzel összefüggésben egy emberi jogi minimum biztosítása, másrészt pedig a tagállamok részére a különleges helyzet hatékony kezeléséhez bizonyos alapvető jogok korlátozhatóságának érvényesítése.

Az Egyezmény 15. cikke lehetővé teszi a tagállamok számára, hogy bizonyos körülmények fennállása esetén derogációval éljenek. Az Egyezmény szerinti derogáció alatt azt értjük, amikor egy állam meghatározott időtartamra felfüggeszti az Egyezményből folyó kötelezettségei teljesítését. A kivételes állapot tehát itt valamely egyezményes jog felfüggesztését jelenti, amely során a kormányzat számára lehetővé válik a különleges helyzet kezelése. ${ }^{22}$ A 15. cikk (2) bekezdése abszolút jogokról rendelkezik, amely jogok nem lehetnek tárgyai a derogációnak. Ezek az élethez való jog (2. cikk), ${ }^{23}$ a kínzás és embertelen vagy megalázó bánásmód tilalma (3. cikk), a rabszolgaság és szolgaság tilalma [4. cikk (1) bekezdés], a visszaható hatályú büntetőtörvények tilalma (7. cikk). Fontos leszögezni, hogy a derogációs lehetőség hatálya az Egyezmény hatályával megegyező, ezért a 15. cikk nem minden háború vagy különleges helyzet során alkalmazandó, hanem csak az 1. cikk szerinti joghatóság alá tartozó esetekben. ${ }^{24}$ Fő szabály szerint abban az esetben tehát, ha az állam nem gyakorol közhatalmat egy terület lakossága felett, akkor a derogáció alkalmazása sem lehetséges, hiszen ha az egyén nem érvényesítheti az Egyezményben foglalt jogokat, akkor értelemszerü, hogy az állam sem élhet a derogáció lehetőségével. ${ }^{25} \mathrm{Ki}$ kell ugyanakkor emelni azt is, hogy az EJEB gyakorlata a későbbiek során részben megváltozott, és figyelemmel az extraterritoriális joghatósággal kapcsolatos kérdésekre, ${ }^{26}$ a Bankovic-ügyben alkalmazott sztenderd meghaladottá vált. Az EJEB az Al-Skeini és mások Egyesült Királyság elleni ügyben ${ }^{27}$ többek között arra a megállapításra jutott, hogy bár az Egyezmény 1. cikkében foglalt joghatóság elsődlegesen territoriális jellegü, ugyanakkor vannak kivételes körülmények, amikor a joghatóság extraterritoriális jelleggel bír. Az ún. „State agent authority and control"-on alapuló joghatóság (a külföldön tartózkodó diplomaták és konzuli szolgálatot teljesítők) esetében elfogadhatóvá válik, hogy a részes állam a jogok egy meghatározott körét köteles csak biztosítani, az Egyezmény egészével szemben,

22 GuILD, Elspeth: Mikor büncselekmény a háború? - Biztonság és európai emberi jogok: az egyéni jogok védelme szükséghelyzet és fegyveres összeütközés idején. L'Harmattan, Budapest, 2009, 46.

23 Ez alól egyetlen kivételt a jogszerü háborús cselekmények következtében okozott halálesetek jelentenek. A jogszerü háborús cselekmény fogalmának két eleme van: a háborúindítás jogszerüsége és a hadviselés módjának jogszerüsége. GuILD: i. m., 47. E két elemen kívül megkülönböztethető még egy harmadik is, amely a demokrácia helyreállítása, illetőleg emberi jogok védelme érdekében történő beavatkozás. Erről részletesen: ByERs, Michael: War Law. Gove Press, New York, 2005, 85-111.

24 Erre a megállapításra jutott az EJEB többek között: Bankovic és mások kontra Belgium és mások ügy, 2001. december 12-i határozat (ügyszám: 52207/99), 62. pont.

25 GuILD: i. m., 49.

26 SzEMESI Sándor: A területi joghatóság gyakorlásának egyes kérdései az Emberi Jogok Európai Bírósága gyakorlatában. In: Blutman László (szerk.): Ünnepi kötet dr. Bodnár László egyetemi tanár 70. születésnapjára. Szeged, 2014, 501-514.

27 Al-Skeini és mások kontra Egyesült Királyság ügy, 2011. július 7-i ítélet (ügyszám: 55721/07). 
míg az ún. „effective control over an area”-n alapuló joghatóságnál (amikor katonai múvelethez kapcsolódóan az állam tényleges ellenőrzési jogkört gyakorol határain túli területeken) mindez csak elvárás. ${ }^{28}$ Hasonlóan abszolút tilalmakat és eltérést nem engedő garanciális szabályokat tartalmaz az Egyezmény halálbüntetés eltörléséről szóló 6. kiegészítő jegyzőkönyvének 3. cikke, a 7. kiegészítő jegyzőkönyv 4. cikk (3) bekezdése, illetve a halálbüntetés minden körülmények között történő eltörlésére vonatkozó jegyzőkönyvének kihirdetéséről szóló 13. kiegészítő jegyzőkönyv ${ }^{29}$ (2) cikke.

Az Egyezmény a derogációra vonatkozóan szigorú eljárási garanciákat követel meg a tagállamoktól. Mindenekelőtt az érintett kormánynak értesíteni kell az Európa Tanács fötitkárát a derogáció kinyilvánításáról. Az értesítés indokolásában a derogáció alkalmazásának alapjául szolgáló körülményeket kell bemutatni. A kormányzat továbbá köteles meghatározni a derogációval érintett alapvető jogokat, az intézkedéseknek pedig arányban kell állniuk a különleges helyzet súlyával. Nagyon fontos kiemelni, hogy a derogációról szóló értesítés nem jelenti annak feltétel nélküliségét, annak vitatása esetén a jogszerüség indokolása a kormányzatot terheli. ${ }^{30} \mathrm{Ez}$ a mechanizmus azt is jelenti, hogy a kivételes állapot nem teljes mértékben az adott állam szuverén döntése. ${ }^{31}$

A 15. cikk - más derogációs szabályokhoz hasonlóan - rendelkezik időbeli korláttal, ${ }^{32}$ amely szerint a derogáció érvényessége csak arra az időre korlátozódik, amíg a nemzet létét fenyegető rendkívüli állapot fennáll. Az EJEB ezzel összefüggésben a Brannigan és McBride kontra Egyesült Királyság ügyben ${ }^{33}$ az Észak-Írországban fennálló kivételes állapottal összefüggésben vizsgálta ezt az érvet. Az Észak-Írországban tapasztalt terrorista erőszak hatására az Egyesült Királyság elfogadta a terrorizmus megelőzését célzó ideiglenes rendelkezésekről szóló 1984. évi törvényt, amely többek között lehetővé tette az elfogatóparancs nélküli letartóztatást arra az esetre, ha az adott személy terrorizmussal kapcsolatos büncselekmények elkövetésével vagy előkészületével gyanúsítható. A kormány hivatkozott arra, hogy 1974 óta a terrorizmussal szembeni harc miatt szükség volt a letartóztatás és őrizetben tartás meghosszabbítását lehetővé tevő jogkörökre. ${ }^{34} \mathrm{Az}$ ügy közvetlen előzménye, hogy az Egyesült Királyság 1984 augusztusában visszavonta a 15. cikk szerinti derogációját, melynek következtében számos eljárás indult a Bíróság előtt az Egyesült Királysággal szemben. Ezek közül kiemelkedett a Brogan és mások kontra Egyesült

28 A „State agent authority and control”-on, valamint az „effective control over an area”-n alapuló joghatósággal kapcsolatos kivételekről részletesen: Harris, David-O’Boyle, Michael-Bates, Ed-Buckley, Carla (eds.): Law of the European Convention on Human Rights. Oxford University Press, Oxford, 2014, 99-100.

29 A jegyzőkönyvet a hazai jogba az emberi jogok és alapvető szabadságok védelméről szóló, Rómában, 1950. november 4-én kelt Egyezmény tizenharmadik, a halálbüntetés minden körülmények között történő eltörlésére vonatkozó jegyzőkönyvének kihirdetéséröl szóló 2004. évi III. törvény ültette át.

30 GuILD: i. m., 56.

31 GuILD: i. m., 57.

32 Lehmann: i. m., 109.

33 Brannigan és McBride kontra Egyesült Királyság ügy, 1993. május 26-i ítélet (ügyszám: 14553/89, 14554/89).

34 Berger, Vincent: Az Emberi Jogok Európai Bíróságának joggyakorlata. Officina Tannyomda, Szeged-Budapest, 1999, 97. 
Királyság ügy, ${ }^{35}$ amelyben az EJEB elmarasztalta az Egyesült Királyságot, kimondva az 5. cikk megsértését. Az Egyesült Királyság választási kényszer elé állt: vagy bevezeti az őrizetben tartást elrendelő döntések bírói felülvizsgálatát, vagy pedig ismételten derogációval él. A kormány az utóbbit választotta, és 1988-ban tájékoztatta a fötitkárt, hogy (ismételten) derogációval kíván élni annak érdekében, hogy Észak-Írországban kivételes intézkedésként szigorúbb fogva tartási szabályokat vezethessen be. A kormány az Egyezmény 15. cikk (1) bekezdésében megfogalmazott eltérés jogával azokra az esetekre vonatkozóan kívánt élni, amikor a törvény rendelkezései sértették volna az Egyezmény 5. cikk (3) bekezdését. A kérelmezők arra hivatkoztak, hogy az Egyezmény 5. cikk (3) bekezdése ellenére nem állították őket haladéktalanul bíróság elé, ráadásul a sérelemmel szemben nem volt jogorvoslati lehetőségük és kártérítést sem követelhettek. Az EJEB döntésében elvetette azon érvet, miszerint a derogáció csak akkor megengedett, ha a kezdeti derogáció visszavonását követően a helyzet romlik. ${ }^{36} \mathrm{Nem}$ megkérdőjelezhető a derogáció alkalmazásának érvényessége pusztán azon az alapon, hogy a tagállam egy korábbi döntés érvei alapján tanulmányozta a lehetőségét olyan módszer kidolgozásának, amely lehetővé tenné, hogy jobban megfeleljen az Egyezmény szerinti kötelezettségének. ${ }^{37}$ Ennél jóval konkrétabb megállapítást tett az EJEB az időbeliség kérdésében az $A$. és mások kontra Egyesült Királyság ügyben, amikor lefektette, hogy 2001. szeptember 11. után az Egyesült Királyság által tett derogációs intézkedések - amelyeket egyébként a parlament folyamatosan felülvizsgált -, nem tekinthetök érvénytelennek pusztán arra hivatkozással, hogy nem voltak „átmeneti” jellegủek. ${ }^{38}$

\section{A „nemzet létét fenyegető más rendkívüli állapot”}

Az Egyezmény 15. cikke szerinti derogációs rendelkezés értelmében az Egyezmény egyes rendelkezései felfüggesztésére abban az esetben van lehetőség, hogy ha "háború vagy a nemzet létét fenyegető más rendkívüli állapot" miatt ez feltétlenül szükséges. Ez az Egyezmény 15. cikke alkalmazhatóságának első és egyben legfontosabb eleme is. Ezen belül is a „nemzet létét fenyegető rendkivüli állapot" meghatározás a leginkább problémás, a háborúra történő hivatkozás sokkal egyértelmübb. ${ }^{39} \mathrm{~A}$ háború egyébként a 15 . cikk alkalmazása tekintetében az államok közötti fegyveres összeütközésekre utal. ${ }^{40}$

A 15. cikk területileg meghatározott események alapján is felhívható, feltéve, hogy hatásának a nemzet egészére kiható jellege van. Az EJEB egy konkrét ügyben például - ahol a kormány a terrorizmus veszélyére hivatkozással, de az eltéréssel kapcsolatos főtitkári tájékoztatásban megjelölt területi hatályon kívüli régióban kívánt

35 Brogan és mások kontra Egyesült Királyság ügy, 1988. november 29-i ítélet (ügyszám: 11209/84, 11234/84, 11266/84, 11386/85).

36 A Brannigan és McBride kontra Egyesült Királyság ügyben hozott ítélet, 45. pont.

37 BERger: i. m., 97.

38 A. és mások kontra Egyesült Királyság ügy, 2009. február 19-i itélet (ügyszám: 3455/05), 178. pont.

39 VAN DIJK-VAN Hoof: i. m., 735.

40 Grabenwarter, Christoph: Europäisches Menschenrechtskonvention. Verlag C. H. Beck, Munich, 2008, 11. 
élni az őrizetbe vételre vonatkozó, és az eltéréssel érintett területen egyébként alkalmazott szigorúbb szabályokkal - arra a megállapításra jutott, hogy a kormány nem hivatkozhat a 15. cikkre, amennyiben az ügy alapjául szolgáló esemény nem az eltéréssel érintett régióban történt. Végső soron pedig a Bíróság arra a megállapításra jutott, hogy az eltérés kérdése az ügy körülményeire tekintettel fel sem merül, vagyis a 15. cikk nem volt alkalmazható. ${ }^{41}$

A nemzet létét fenyegető rendkivüli állapot úgy határozható meg, hogy az mindazon kivételes és fenyegető veszéllyel járó különleges helyzet, amely hatását nagy nyilvánosság elött fejti ki, és veszélyt jelent a kérdéses államot alkotó közösség rendezett müködésére. ${ }^{42} \mathrm{Az}$ EJEB Lawless-ügyben ${ }^{43}$ hozott döntése abból az aspektusból is jelentős, hogy itt fektette le a Bíróság a derogáció kritériumrendszerét. Az ügy hátterében Írország 1957-es derogációja állt, amelyet azzal indokoltak, hogy egy milicista szervezet (IRA) alkotmányellenes tevékenységet végez az ország egy meghatározott területén. Az érvelés kitért arra is, hogy a szervezet tevékenysége nemcsak az ország területére, hanem többek között az Egyesült Királyságra is kiterjed. A kérelmező 1961-ben fordult az EJEB-hez, arra hivatkozva, hogy a derogáció idején bírósági eljárás nélkül tartották fogva. Az EJEB mindenekelőtt megállapította: az Egyezmény hatálya nem terjed ki arra, hogy az egyes tagállamok saját maguk állapítsák meg a 15. cikk hatályát, a tagállami felelősség csak addig terjed, hogy az állam értesítse a főtitkárt a derogációról. Az EJEB fenntartja a jogot arra, hogy megvizsgálja, vajon a derogáció feltételei teljesültek-e..$^{44} \mathrm{~A}$ Lawless-ügy további fontos aspektusa volt, hogy definiálta a különleges helyzetet (vagyis az Egyezmény szerinti „más rendkívüli állapotot”) is. Az Egyezmény 15. cikk (1) bekezdése szerinti rendkívüli állapot (azaz különleges helyzet) három feltétel teljesülése esetén áll fenn: a) olyan különleges krízis- vagy veszélyhelyzetekröl legyen szó, b) amelyek a teljes lakosságot érintik, $c$ ) és végezetül veszélyt jelentenek azon közösségek szervezett életére, amelyek az államot alkotják. ${ }^{45} \mathrm{~A}$ mindenkori kormányzat felelössége továbbá ebben a tekintetben a társadalom egyes tagjainak a védelme. A kormányok részére ugyanakkor biztosítani kell bizonyos mérlegelési szabadságot (a mérlegelési jogkör doktrínájáról részletesen a következő címben lesz szó), annak eldöntése érdekében, hogy a konkrét helyzet valóban olyan különleges helyzet, amely a nemzet létét fenyegeti, és olyan kivételes intézkedéseket tesz szükségessé, amely kizárólag az Egyezményben foglalt kötelezettségek felfüggesztésével lehetséges. ${ }^{46}$ A konkrét ügyben egyébként az EJEB arra az álláspontra jutott, hogy Lawless örizetben tartása a szerződő állam 15. cikk (1) bekezdése által elismert jogán alapszik. A szóban forgó időszakban a nemzet létét fenyegető rendkívüli állapot állt fenn, ugyanis Észak-Írország területén az alkotmányos rend megdöntését célzó fegyveres szervezet müködött, amely céljai elérésére erőszakot alkalmazott.

41 Abdülsamet Yaman kontra Törökország ügy, 2004. november 2-i ítélet (ügyszám: 32446/96), 68-70. pontok.

42 Lawless kontra Írország ügy, 1959. december 19-i bizottsági jelentés, 82. pont.

43 Lawless kontra Írország ügy (No. 3), 1961. július 1-i ítélet (ügyszám: 332/57).

44 A Lawless kontra Írország ügyben hozott itélet, 45-47. pontok.

45 A Lawless kontra Írország ügyben hozott itélet, 28. pont: "they refer to an exceptional situation of crisis or emergency which affects the whole population and constitutes a threat to the organised life of the community of which the State is composed".

46 A Lawless kontra Írország ügyben hozott itélet, 39-48. pontok. 
Az ún. „görög ügy” Dánia, Norvégia, Svédország és Hollandia, Görögországgal szembeni ügye volt az azóta már megszünt Emberi Jogok Európai Bizottsága elött. ${ }^{47}$ Az ügy egyik sajátossága, hogy atipikus módon részes államok egymás közötti vitáján alapult. Az eset hátterében az 1967-es görögországi államcsíny állt, amelyet követően a katonai vezetésű kormányzat bizonyos alapvető jogok felfüggesztéséről határozott, és értesítette a fötitkárt, hogy az Egyezmény 15. cikke alapján derogációt kíván alkalmazni, figyelemmel a közrendet és az állam biztonságát veszélyeztető helyzetre. Bár a Bizottság azt állapította meg, hogy a 15. cikkben foglalt feltételek nem teljesültek, meghatározta a nemzet létét fenyegető más rendkívüli állapot alapvető, további jellemzőit. Ennek megfelelően a nemzet létét fenyegető veszély tényleges és valódi, a közösség egészét fenyegető és a közösség szervezett életét zavaró állapot, amely rendkívüli, abban a vonatkozásban, hogy a közbiztonság fenntartása, az állami és társadalmi rend megóvása érdekében az Egyezmény által biztosított hagyományos intézkedések és korlátozási lehetőségek már nem elégségesek. ${ }^{48} \mathrm{Az}$ érintett időszakban egyébként a Bizottság szerint Görögországban nem volt különleges helyzet, a rendvédelmi szervek nem voltak teljesítőképességük határán. A mindenkori kormányzat felelőssége ugyanis annak bizonyítása, hogy az Egyezmény hatályának felfüggesztéséhez szükséges körülmények megvalósultak, ${ }^{49} \mathrm{ez}$ utóbbi követelménynek pedig a kormány a Bizottság megítélése szerint nem tett maradéktalanul eleget.

Egy másik, szintén államok között fennálló ügyben az EJEB hasonló körülmények között, de már elfogadta a nemzet létét fenyegetö rendkívüli állapot fennállását. $A z$ EJEB az Írország kontra Egyesült Királyság ügyben ${ }^{50}$ ismételten az észak-írországi helyzetet vizsgálta. 1976-ban a kérelmező az Egyezmény 3., 5., 6., 14. és 15. cikkei Egyesült Királyság általi megsértésének megállapítását kérte. A kérelmező előadta, hogy az észak-írországi területen érvényesülö terrorizmusellenes intézkedések alapján diszkriminatív módon tartanak fogva bírósági eljárás nélkül állampolgárokat. Bár a derogáció a kínzás, embertelen megalázó bánásmód tekintetében nem érvényesülhet, Írország mégis hivatkozott arra, hogy az Egyesült Királyság hatóságai egy speciális kényszervallatási technika, az úgynevezett „öt módszer” alkalmazásával hallgattak ki gyanúsítottakat. Az EJEB ugyanakkor ebben a kérdésben - mivel erre nem vonatkozhat derogáció - külön vizsgálatot végzett. A Bizottság görög ügyben alkalmazott megközelítésén az EJEB változtatott, és amíg ott a rendvédelmi szervek teljesítőképességének határát vizsgálta, addig itt már az erőszak magas

47 A görög ügy (Dánia kontra Görögország, Norvégia kontra Görögország, Svédország kontra Görögország, Hollandia kontra Görögország), az Emberi Jogok Európai Bizottsága határozata (ügyszám: 3321/67, $3322 / 67,3323 / 67,3344 / 67)$.

48 Van DiJK-VAN Hoof: i. m., 736; CRYsleR, Edward: Brannigan and McBride v. the U.K.: A New Direction on Article 15 Derogations under the European Convention on Human Rights. Revue Belge de Droit International, Éditions Bruylant, Bruxelles, 1994/2, 607.

49 Grossman M., Claudio: States of Emergency: Their Impact on Human Rights. American Journal of International Law, 1985/4, 1104-1106.

50 İrország kontra Egyesült Királyság ügy, 1978. január 18-i ítélet (ügyszám: 5310/71). 
szintjére hívta fel a figyelmet, ${ }^{51}$ ez pedig az EJEB megítélése szerint már túllépett az egyszerü rendzavarás, polgári engedetlenség kategóriáján. ${ }^{22} \mathrm{~A}$ Bíróság szerint Észak-Írországban olyan különleges helyzetről lehetett beszélni, amely kimerítette az Egyezmény 15. cikkében foglaltakat. ${ }^{53}$ Jelen ügy további fontos aspektusa volt az a megállapítás, hogy a különleges helyzet Észak-Írországra korlátozódik, vagyis nem az Egyesült Királyság egészét érinti. Mind a Lawless-ügyben, mind pedig a görög ügyben követelményként határozta meg az EJEB, hogy különleges helyzet csak az lehet, amely a lakosság egészét érinti. Az állam területének egészére való kihatás innentöl már nem feltétel, hanem elegendő, ha a különleges helyzet az állam egy jól körülhatárolt területét érinti. Hangsúlyozni kell ugyanakkor azt is, hogy az EJEB döntéseinek indokolása továbbra is a lakosságra és nem a területre vonatkozik. ${ }^{54}$

A Brannigan-ügy a derogáció alkalmazhatóságának egyik fontos esetét jelentette, hiszen az Egyesült Királyság azért élt az eltérés lehetöségével, hogy így kerülje meg az Egyezményben foglalt kötelezettségeit. Az ügyben a tagállam az örizet tartamát úgy hosszabbította meg az EJEB által irányadónak tekintett általános mértéket jelentősen meghaladva, hogy a 15. cikkre hivatkozással felfüggesztette az Egyezmény hatályát. Az ügyhöz előzményként az EJEB Brogan-ügyben hozott döntése szolgált, amely során az EJEB azért marasztalta el a brit kormányt, mert az általa alkalmazott legrövidebb tartamú - bírósági eljárást mellőző - fogva tartás időtartama meghaladta az Egyezmény „bíró elé állitás haladéktalan volta"55 fogalma által biztosított szigorú határokat. Igaz a bíróság elismerte, hogy a terrorizmus elleni küzdelem megnehezítheti egy tagállam helyzetét, ezáltal mintegy burkoltan jelezte az Egyezménytől való eltérés lehetőségét. Az EJEB a Brannigan ügyben megállapította, hogy az Egyesült Királyság eltérési jogának gyakorlása az Egyezmény 15. cikkében foglalt elöírásoknak megfelelő tájékoztatás alapján történt, a kérelmezők így nem hivatkozhattak eredményesen az Egyezmény általuk felhívott cikkében foglalt jogok sérelmére.

Fontos hangsúlyozni, hogy a döntés nem volt egyhangú, négy bíró különvéleményt fogalmazott meg. Walsh bíró kiemelte, hogy a letartóztatások valódi célja az volt, hogy a kérelmezők saját magukra nézve terhelő vallomást tegyenek, mely eljárás az Egyezménybe ütközik. Felhívta a figyelmet továbbá arra is, hogy az Egyezmény 5 . cikke szerinti eljárási garanciák be nem tartása elvezethet a 3 . cikk szerinti

51 Erröl részletesen: Írország kontra Egyesült Királyság ügyben hozott itélet, 29-33, 37, 45-48. pontok. A bombatámadások, zavargások, lövöldözések mint erőszakos cselekmények száma 1970 és 1971 között jelentősen megnövekedett.

52 GuILD: i. m., 50.

53 Az Írország kontra Egyesült Királyság ügyben hozott ítélet, 205. pont.

54 Svensson-McCARTHy, Anna-Lena: The International Law of Human Rights and States of Exception. Martinus Nijhoff Publishers, the Hague, 1998, 309.

55 Ezzel összefüggésben hangsúlyozandó, hogy az Egyezmény 5. cikk 3. bekezdés „haladéktalan” bíró elé állítás időtartamának pontos meghatározására az EJEB nem vállalkozott, azt a konkrét esetek összes körülményei vizsgálata alapján dönti el. Ugyanakkor a legkisebb tartam vonatkozásában valamennyi ügy körülményeit figyelembe véve 3-4 nap tekinthető a felső határnak. A határidő számítása objektív, vagyis az időtartam meghatározása során a tagállamok nem hivatkozhatnak nemzeti ünnepre, hétvégére, vagy éppen a terrorcselekményeknek egy bizonyos területen vagy államban történő elszaporodására, különleges helyzetre. Erről részletesen: GRÁD András-WeLLER Mónika: A strasbourgi emberi jogi bíráskodás kézikönyve. HVG-ORAC, Budapest, negyedik, bővített kiadás, 2011, 215-216. 
tilalom megsértéséhez (kínzás tilalma), amely abszolút jog. Véleménye szerint a bírák feladata, hogy a személyes szabadságot érintő kérdésekben döntsenek, ezért a kormánynak ki kellett volna dolgoznia a megfelelő eljárást. A többségi álláspontot azért is tartotta tévesnek, mert a tagállami hatóságok feladata, hogy az Egyezményben foglaltaknak megfeleljenek, nem pedig fordítva. A többségi döntés ugyanis abba az irányba mutat, amelynek célja az Egyezmény „átformálása” a tagállami igényeknek megfelelően. ${ }^{56}$ Pettiti bíró különvéleményében hangsúlyozta: a körülmények alapján nem volt egyértelmü, hogy a terrorizmus jelentette fenyegetettség a Broganügy és jelen ügy kérelmezőinek letartóztatása közötti periódusban számottevően növekedett volna. Fontosnak tartotta kiemelni, hogy az Egyezmény 15. cikke nem szolgálhat a tagállamok részére egyfajta biankó csekként az olyan esetekre, amikor az Egyezményben foglalt kötelezettségeiknek nem tudnak eleget tenni. ${ }^{57}$ De Meyer bíró is a Brogan-ügyre utalt vissza különvéleményében és azt hangsúlyozta, hogy a derogáció alkalmazásának indoka is az intézmény visszaélésszerủ alkalmazására utalt. Arra ugyanis azért volt szüksége a kormánynak, mert tisztában volt vele, hogy a terrorizmussal gyanúsítható személyek bíróság elé állítás nélküli, hét napnál tovább történő fogva tartása sértené az Egyezményt. Az EJEB Brogan-ügyben hozott döntésében foglaltak alapján - az ismételt sérelmes döntéstöl tartva - jelen ügyben az Egyezménytöl való eltérés mellett döntött. ${ }^{58}$ Makarczyk bíró különvéleményében arra hívta fel a figyelmet, hogy az Egyezménytöl való eltérés egyik tagállam általi alkalmazása közvetetten kihat valamennyi tagállamra. Hangsúlyozta, hogy az újonnan csatlakozott szerződő államok számára - utalva többek között a volt szocialista országokra - az Egyezményhez történő csatlakozás egyúttal az egységes európai értékrendhez, a joguralomhoz és a demokratikus értékekhez való csatlakozást jelentette. Valamennyi, az Egyezmény 15. cikkével kapcsolatos EJEB-döntés más hatással lehet Kelet-Közép-Európa új demokráciáira, mint a komoly demokratikus hagyományokkal rendelkező régebbi tagállamokra. Éppen ezért az EJEB-nek nagy körültekintéssel kell eljárnia ezekben az ügyekben, az Egyezmény alkalmazásával kapcsolatos visszaélések lehetőségét pedig ki kell zárnia. Felhívta a figyelmet arra is, hogy a döntés végső soron kiskaput nyit a bírói felülvizsgálat nélküli, határozatlan ideig tartó őrizetben tartás gyakorlatához. A bíró végül hiányolta a kormányzat kétséget kizáró bizonyítékait arra vonatkozóan, hogy a bírói felülvizsgálat nélküli határozatlan ideig tartó örizetben tartás a terrorizmus elleni küzdelem hatékony és feltétlenül szükséges eszköze lenne. ${ }^{59}$

56 A Brannigan és McBride kontra Egyesült Királyság ügyben hozott ítélet, Walsh bíró különvéleménye.

57 A Brannigan és McBride kontra Egyesült Királyság ügyben hozott ítélet, Pettiti bíró különvéleménye.

58 A Brannigan és McBride kontra Egyesült Királyság ügyben hozott ítélet, De Meyer bíró különvéleménye.

59 A Brannigan és McBride kontra Egyesült Királyság ügyben hozott ítélet, Makarczyk bíró különvéleménye. 


\section{A mérlegelési jogkör doktrínája és az Egyezmény 15. cikke}

A derogáció részes állam általi alkalmazhatóságának nagyon fontos aspektusa a mérlegelési jogkör doktrínájának (margin of appreciation) ${ }^{60}$ következetes alkalmazása. Az elvet az Egyezmény sokáig nem tartalmazta ${ }^{61}$ azonban a 15 . kiegészítő jegyzőkönyv 1. cikke az Egyezmény preambulumát kiegészíti a tagállamok mérlegelési jogkörének elismerésével. ${ }^{62} \mathrm{~A}$ doktrínát az EJEB pont az Egyezmény 15. cikkével kapcsolatban dolgozta ki, ám az más ügyekben is nagyon fontos elvvé vált a Bíróság gyakorlatában. A tanulmány terjedelmi és tartalmi korlátain jelentősen túlmutatna a mérlegelési jogkör doktrínájának az Egyezmény egésze szempontjából történő ismertetése, ezért jelen cím csak a doktrína 15. cikkel összefüggésbe hozható bemutatását végzi el. Az Egyezmény 15. cikkének derogációs rendelkezése mindazonáltal jelentős problémát jelentett és jelent mind a mai napig az EJEB számára, hiszen lényegében politikai szempontok alapján engedte meg az eltérés lehetőségét a tagállamok számára. Ugyanakkor ez a rendelkezés és annak említett jellemzői vezettek el a mérlegelési jogkör doktrínájának kidolgozásához. ${ }^{63}$ Polgári Eszter doktori értekezésében rámutatott arra, hogy a doktrína megítélését illetően három eltérő nézet ismert. ${ }^{64} \mathrm{Az}$ egyik megközelítés szerint a doktrína arra szolgál, hogy biztosítsa az EJEB számára a döntéshozatal felelősségének elhárítását, vagyis „a Bíróság opportunista megközelítését" ${ }^{\prime 65}$ fejezi ki. ${ }^{66} \mathrm{~A}$ másik arra hívja fel a figyelmet, hogy az EJEB a doktrínát arra használhatja fel, hogy kivonja magát „a döntést megalapozó indokok"67 megfogalmazása alól. ${ }^{68} \mathrm{~A}$ harmadik irányzat viszont elfogadja a "tagállamoknak biztosított mérlegelési szabadságot mint legitim értelmezési alapelvet”. 69

60 A mérlegelési jogkörről bővebben lásd SzEMESı Sándor: A diszkrimináció tilalma az Emberi Jogok Európai Bírósága gyakorlatában. CompLex, Budapest, 2009, 64. Lásd továbbá LEGG, Andrew: The Margin of Appreciation in International Human Rights Law: Deference and Proportionality. Oxford University Press, 2012.

61 Spielmann, Dean: Allowing the Right Margin the European Court of Human Rights and the National Margin of Appreciation Doctrine: Waiver or Subsidiarity of European Review? Centre for European Legal Studies, University of Cambridge, 2012, 2.

62 „Megerősítve, hogy - a szubszidiaritás elvével összhangban - elsődlegesen a Magas Szerződő Felek kötelessége a jelen Egyezményben és az ahhoz füzött jegyzőkönyvekben meghatározott jogok és szabadságok biztositása, és hogy ennek során a Magas Szerződő Felek az Egyezmény által létesített Emberi Jogok Európai Bíróságának ellenőrzési jogköre alá eső mérlegelési jogkörrel rendelkeznek..."

63 Többek között a doktrínával foglalkozik részletesen POLGÁRı Eszter: A tagállami jog-összehasonlítás az Emberi Jogok Európai Bíróságának gyakorlatában. Fundamentum, 2012/3, 53-57.

64 PolgÁrı Eszter: Az összehasonlító jog az Emberi Jogok Európai Bíróságának gyakorlatában, különös tekintettel az európai konszenzus vizsgálatára. PhD-értekezés, Eötvös Loránd Tudományegyetem Állam- és Jogtudományi Doktori Iskola, Budapest, 2011.

65 Polgári: i. m., 35.

66 Vesd össze O'Donnell, T. A.: The Margin of Appreciation Doctrine Standards in the Jurisprudence of the European Court of Human Rights. Human Rights Quarterly, 1982/4, 476.

67 Polgári: i. m., 35.

68 Vesd össze Lord Lester of Herne Hill, Q. C.: The European Convention on Human Rights in the New Architecture of Europe. In: Proceedings of the $8^{\text {th }}$ International Colloquy on the European Convention on Human Rights. Council of Europe, Strasbourg, 1995, 236-237.

69 Polgárl: i. m., 35. Vesd össze Mahoney, Paul: Marvelous Richness of Diversity or Invidious Cultural Relativism? Human Rights Law Journal, 1998/1, 1-2. 
A mérlegelési jogkör doktrínájának eredete az EJEB felállítását megelőző időre, 1958-ra tehető. A Bizottság a Ciprus ügyben alkalmazta először a terminológiát, amikor is megállapította, hogy az alperes kormány számára az Egyezmény 15. cikke alapján bizonyos mértékü mérlegelés biztosított. ${ }^{70} \mathrm{~A}$ már korábban említett Lawlessügyben a Bizottság azt hangsúlyozta, hogy a tagállamokat megilleti bizonyos mértékü mérlegelési jog annak eldöntésekor, hogy fennáll-e a nemzet létét fenyegető rendkívüli állapot. A kormány felelőssége, hogy az Egyezmény 15. cikkének megfelelően az alapjogok korlátozásának kérdésében határozzon, míg az EJEB-nek az a feladata, hogy felülvizsgálja e kormányzati döntések jogszerűségét. ${ }^{71}$ Az EJEB végül az Írország kontra Egyesült Királyság ügyben mondta ki, hogy elsődlegesen a tagállamok felelőssége annak eldöntése, hogy vajon fennáll-e a nemzet létét fenyegető rendkívüli állapot. Amennyiben ez megállapítható, úgy a különleges helyzet elhárításához szükséges intézkedések megtétele is az ő felelősségük. A tagállami hatóságok ugyanis egy nemzetközi bírósághoz képest általában jobb helyzetben vannak a különleges helyzet fennállásának megítélésében, valamint annak eldöntésében, hogy milyen jellegü és terjedelmü derogáció szükséges annak elhárításához. ${ }^{72} \mathrm{Az}$ EJEB többek között az Aksoy-ügyben ${ }^{73}$ hangsúlyozta, hogy a mérlegelési jogkör felett felügyeleti jogot gyakorol abban a kérdésben, hogy az intézkedések valóban szükségesek-e a különleges helyzettel szembeni védekezés érdekében. Az Egyezmény által garantált jogok valamelyikét érintő derogáció jogszerüségének kérdése tehát nem kizárólag a részes állam által eldöntendő kérdés. ${ }^{74}$ Ezzel összefüggésben az EJEB felülvizsgálati jogkörének gyakorlása során megfelelően mérlegelnie kell a derogáció által érintett jogok természetét, a kivételes állapot időtartamát és az annak kialakulásához vezető körülményeket. ${ }^{75}$ Ezzel az EJEB gyakorlatilag lefektette a 15. cikkel kapcsolatos teszt alapvető elveit, amelyet a gyakorlatában a mai napig következetesen alkalmaz. ${ }^{76}$ A szükséges mérték objektív, általános meghatározása azonban nem lehetséges, így mindig a konkrét ügy kapcsán kell kijelölni a feltétlenül szükséges mértéket. ${ }^{77}$

A mérlegelési jogkör és a derogáció során alkalmazott intézkedések felülvizsgálata felveti az „arányosság” kérdését is. Az arányosság alapelve három összetevőre bontható, amely az intézkedés súlyával, időtartamával és hatályával van kapcsolatban. ${ }^{78}$ Ennek keretében tehát az intézkedésnek ${ }^{79}$ összefüggésben kell állnia a különleges helyzettel, annak a veszély elhárítására alkalmasnak kell lennie, illetöleg

70 Ciprus ügy (Görögország kontra Egyesült Királyság), az Emberi Jogok Európai Bizottságának jelentése (ügyszám: 176/56), 174-179, 176.

71 Yourow, Howard Charles: The Margin of Appreciation Doctrine in the Dynamics of European Human Rights Jurisprudence. Kluwer, Hague, 1996.

72 Az Írország kontra Egyesült Királyság ügyben hozott ítélet, 207. pont.

73 Aksoy kontra Törökország ügy, 1996. december 18-i ítélet (ügyszám: 21987/93).

74 GUILD: i. m., 56-57.

75 Berger: i. m., 96.

76 CRYsler: i. m., 609.

77 A Lawless kontra Írország ügyben hozott itélet, 28. pont; az Aksoy kontra Törökország ügyben hozott itélet, 69-70. pontok.

21278 CRYSLER: i. m., 612.

79 Erröl részletesebben CRYSLER: i. m., 613. 
garanciális szabályokat (például jogorvoslati lehetőséget) kell biztositani az esetleges visszaélésekkel szemben. ${ }^{80}$ További fontos elem, hogy az intézkedés csak akkor alkalmazható, ha nem áll rendelkezésre egyéb, kevésbé jogkorlátozó megoldás, ${ }^{81}$ de ezek az intézkedések is csak a feltétlenül szükséges mértékig alkalmazhatók. Nem lehetnek továbbá ellentétesek az állam nemzetközi jogból fakadó egyéb kötelezettségeivel. ${ }^{82} \mathrm{~A}$ konkrét esetekben mindig rendkívül nehéz az EJEB feladata annak eldöntésekor, hogy az adott helyzet mikor válik különlegessé. ${ }^{83}$ Általánosságban megállapitható, hogy az EJEB gyakorlatában elfogadottá vált, miszerint a terrorcselekmény indukálta fenyegetettséggel szemben a hagyományos jog által biztosított keret nem elegendő. ${ }^{84} \mathrm{Az}$ ilyen helyzetekben pedig a derogáció indokolt lehet, figyelemmel arra, hogy az Egyezmény által biztosított hagyományos intézkedés lehetőségei alkalmatlanok az adott helyzet kezelésére. ${ }^{85}$

\section{A „terrorizmus elleni háború viszonya” a 15. cikkhez}

A 2001. szeptember 11-ét követően használt „terrorizmus elleni háború” terminológia ellentmondásos jellegére számos szerző felhívta a figyelmet. ${ }^{86} \mathrm{~A}$ kérdés a helyzet értelmezése az Egyezmény 15. cikkének háború vagy a nemzet létét fenyegető más rendkívüli állapot terminológiájában. Ez az új retorika ugyanis a biztonság érdekében történő és az alapvető jogokat érintő új fenyegetésnek is tekinthető. ${ }^{87} \mathrm{Az}$ EJEB a korábbi gyakorlatának megfelelően elismerte, hogy a terrorizmus elleni küzdelem és a terroristák felkutatása kétségtelenül nehéz feladat elé állítják a nemzeti hatóságokat, ${ }^{88}$ sőt, miként arra az előző címben utaltam, a derogáció alkalmazására

80 Chowdhury, S. R.: The Rule of Law in a State of Emergency - The Paris Minimum Standards of Human Rights Norms in a State of Emergency. Printer Publishers, London, 1989, 104.

81 MANGAN, Brendan: Protecting Human Rights in National Emergencies: Shortcomings in the European System and a Proposal for Reform. Human Rights Quarterly, 1988, 372-376.

82 Egyezmény 15. cikk (1) bekezdés utolsó fordulata. Ezzel összefüggésben érdemes megemlíteni azt is, hogy az egyezmény ezen rendelkezése a Bíróság gyakorlatában mintegy kiegészítette az abszolút jogok kategóriáját.

83 KIRCHNER, Stefan: Human Rights Guarantees during States of Emergency: The European Convention on Human Rights. Baltic Journal of Law \& Politics, Vol. 3, No. 1, 2010, 12.

84 A Lawless kontra Írország ügyben hozott itélet, 28. pont; az Írország kontra Egyesült Királyság ügyben hozott ítélet, 4. pont.

85 OVeY, Clare-WHITE, C. A. Robin: Jacobs \& White: The European Convention on Human Rights. Oxford University Press, Oxford, 2006, 443.

86 MıKLósı Zoltán: A terrorizmus elleni „háború” és az emberi jogok. Fundamentum, 2004/3, 43; AcKERMAN, Bruce: Before the Next Attack - Preserving Civil Liberties in an Age of Terrorism. Yale University Press, New Haven-London, 2006, 58-100.

87 LAZARUS, Liora-Goold, Benjamin: Introduction: Security and Human Rights: The Search for a Language of Reconciliation. In: Lazarus, Liora-Goold, Benjamin (eds.): Security and Human Rights. Hart Publishing, Oxford, 2007; MoECKLI, Daniel: Saadi v. Italy: The Rules of the Game Have not Changed. Human Rights Law Review, 2008/3, 534; SMIтH, Richard: The Margin of Appreciation and Human Rights Protection in the 'War on Terror': Have the Rules Changed before the European Court of Human Rights? http://projects.essex. ac.uk/ehrr/V8N1/Smith.pdf 124-125 (2015. 10. 10.).

88 Öcalan kontra Törökország ügy, 2005. május 12-i ítélet (ügyszám: 46221/99), 104. pont. 
is elegendő indok lehet. Ebböl továbbá az a következtetés is levonható, hogy a terrorizmus elleni küzdelem érdekében alkalmazott derogáció során is érvényesül a széles értelemben vett mérlegelés doktrínája. A gyakorlat ugyanakkor azt mutatja, hogy mindez nem jelenti azt, hogy a tagállamok számára pusztán a terrorizmusra történő hivatkozás elegendő lenne az általuk szükségesnek vélt intézkedések megtételéhez. ${ }^{89}$

Az EJEB 2001 előtt nem kívánt az Egyezménynek önálló értelmezést adni a terrorizmus elleni harc körében és érdekében, ${ }^{90}$ vagyis a 15. cikk értelmezési tartománya valamennyi különleges helyzet vonatkozásában azonos volt. Ebböl következően az EJEB nem biztosította a tagállamok számára azt, hogy a terrorizmus elleni küzdelmüket saját hatáskörben végezzék, hiszen az Egyezmény követelményrendszere és szerkezete alkalmas volt a helyzet kezelésére. A tagállamok azonban az új típusú terrorizmus kivételes, speciális jellegére is felhívták a figyelmet. Az olasz kormány a Saadi kontra Olaszország ügyben némileg meglepő módon a terrorizmusra hivatkozott, pontosabban arra, hogy a terrorizmussal összefüggésbe hozható szervezett bủnözés már olyan mértéket öltött, amely a joguralmat veszélyezteti. ${ }^{91} \mathrm{Az}$ érv érdekessége, hogy elvileg éppen a terrorfenyegetettség miatti kivételes állapoti jogkorlátozással járó intézkedések lehetnek azok, amelyek a joguralom számára potenciális veszélyt jelentenek. ${ }^{92} \mathrm{Az}$ ügyben a Bíróság ismételten megerősítette azt a korábbi tételt, miszerint tudomása van a tagállamokat érintő modern kori nehézségekröl, amelyet többek között a növekvő terrorizmus miatt a társadalom biztonságának megóvása érdekében fejtenek ki. ${ }^{93}$ Ezzel a korábbi gyakorlatát tartotta fenn, kifejezésre juttatva, hogy a modern terrorizmus nem igényel speciális elbirálást.

Bár az egyezményes államokban a terrorfenyegetettség növekedése volt tapasztalható a 2001. szeptember 11-i terrortámadásokat követően, azonban csak egyetlen részes állam, az Egyesült Királyság élt a derogáció lehetőségével az Egyezmény 5 . cikke vonatkozásában. ${ }^{94} \mathrm{Az}$ eltérés célja olyan szabályok megalkotása volt, amelyek lehetővé tették külföldi személyek határozatlan idejü fogva tartását. Ennek keretében került elfogadásra az Anti-terrorism Crime and Security Act (2001), amely egyebek mellett biztosította a külügyminisztérium által terroristagyanús személyeknek nyilvánított külföldiek határozatlan idejü fogva tartását. A jogszabály, bár rendkívül szük körben, de lehetővé tette a jogorvoslatot a Special Immigration Appeals

89 SIKUTA, Jan: Threats of Terrorism and th European Court of Human Rights. European Journal of Migration and Law, 2008/1.

90 SмiтH: i. m., 140.

91 Saadi kontra Olaszország ügy, 2008. február 28-i ítélet (ügyszám: 37201/06), 169. pont.

92 Vesd össze Dyzenhaus, David: The Constitution of Law: Legality in a Time of Emergency. Cambridge University Press, Cambridge, 2006.

93 A Saadi kontra Olaszország ügyben hozott itélet, 132. pont.

94 Ez nem azt jelenti, hogy napjainkig ez volt az egyetlen olyan eset, amikor egyezményes állam a terrorizmusra hivatkozással informálta volna az Európa Tanácsot arról, hogy a terrorfenyegetettség miatt szükségállapotot kíván bevezetni, amellyel kapcsolatos intézkedések keretében bizonyos jogok derogálására is sor kerülhet. Franciaország ilyen tartalmú értesítéssel fordult a Tanácshoz 2015. november 25-én. A tagállam különleges helyzetként a 2015-ös párizsi terrortámadásokat jelölte meg. http://www.coe.int/en/web/secretary-general/ news/-/asset_publisher/EYIBJNjXtA5U/content/france-informs-secretary-general-of-article-15-derogationof-the-european-convention-on-human-rights (2016. 09. 05.). 
Commission (a továbbiakban: SIAC) keretében. Ugyanakkor a SIAC eljárási szabályai értelmében a fellebbezők nem tudhatták meg, hogy mivel gyanúsítják őket, valamint azt sem, hogy milyen bizonyítékok alapján tekinthetők veszélyesnek, ha a külügyminisztérium bizalmas információnak minősítette az adatokat. Az ügy abból a szempontból is érdekes volt, hogy először fordult elö, hogy tagállami bíróság (jelen esetben a Lordok Háza) az Egyezmény 15. cikkének alkalmazhatósága kérdésében döntött. ${ }^{95} \mathrm{~A}$ testület mindenekelőtt elfogadta a kormányzat érvelését, miszerint az Egyezmény 15. cikke szerinti nemzet létét fenyegető rendkívüli állapot állt fenn. ${ }^{96}$ Elöször mondta ki egy bírói fórum, hogy a modern kori terrorizmus, pontosabban egy konkrét terrortámadást követö helyzet felveti az Egyezmény 15. cikke és a nemzet létét fenyegető rendkivüli állapot alkalmazhatóságát. A döntés azt is megállapította, hogy a különleges helyzettel összefüggésben aránytalan a csak külföldiekkel szemben megállapított jogkorlátozás, így a szabályozás az Egyezmény 15. cikkének sérelmét a 14. cikkel (diszkrimináció tilalma) összefüggésében valósította meg, tekintettel arra, hogy az eltérés nem volt kellően indokolt. Az ügy ezt követően az EJEB elé került. ${ }^{97}$

Az EJEB mindenekelőtt az ügy speciális jellegére hívta fel a figyelmet, hangsúlyozva, hogy atipikus, ha egy kormányzat saját bírósága döntését támadja meg az EJEB elött. ${ }^{98}$ Ezt követően gyakorlatilag a tagállami bíróság érveivel egyetértve hangsúlyozta, hogy az intézkedések nem érték el a feltétlenül szükséges mértéket a különleges helyzet kezelésére. ${ }^{99} \mathrm{Az}$ EJEB az Írország kontra Egyesült Királyság ügyben elfoglalt álláspontját némileg felülvizsgálva azt mondta, hogy az intézkedések nem voltak összhangban a biztonsági kockázattal, és ezáltal aránytalan és diszkriminatív a terroristák egy csoportját érintő határozatlan ideig tartó fogva tartás. ${ }^{100}$ A mérlegelési jogkör doktrínájával összefüggésben pedig az EJEB fenntartotta eddigi gyakorlatát, de kiegészítette egy, az ügy specialitásából fakadó, korábban nem érvényesített feltétellel, és hangsúlyozta, hogy a mérlegelési jogkör doktrínája az EJEB és a nemzeti hatóságok relációjában érvényesülö eszköz, amely tagállami szintü kérdésekben nem alkalmazható ugyanolyan mértékben. ${ }^{101}$ Az EJEB egyértelművé kívánta tenni, hogy a doktrína az EJEB-tagállamok feletti kontrolljának eszköze, amely nem léphet túl ezen az európai felülvizsgálati rendszeren. ${ }^{102} \mathrm{~A}$ döntés egyesek szerint azért veszélyes, mert az EJEB a tagállami bíróság általi értelmezést hagyta jóvá. Arra az ellentmondásos következtetésre jutott ugyanis, hogy a tagállami bírósági döntéssel ellentétes következtetés csak akkor lenne indokolt, ha a tagállami bíróság az Egyezmény 15. cikkét félreértelmezte volna, vagy az EJEB eddigi

95 A Lordok Háza döntésének itt felhasznált összefoglalásáról: GuILD: i. m., 52-53.

96 A (FC) and others v. Secretary of State for the Home Department, 2004, OKHL, 56.

97 A. és mások kontra Egyesült Királyság ügy, 2009. február 19-i ítélet (ügyszám: 3455/05).

98 Az A. és mások kontra Egyesült Királyság ügyben hozott ítélet, 157. pont.

99 Az A. és mások kontra Egyesült Királyság ügyben hozott itélet, 190. pont.

$100 \mathrm{Az}$ A. és mások kontra Egyesült Királyság ügyben hozott itélet, 186. pont.

101 Az A. és mások kontra Egyesült Királyság ügyben hozott ítélet, 183-184. pontok.

102 Schokkenbroek, Jeroen: The Basis, Nature and Application of the Margin of Appreciation Doctrine in the Case Law of the European Court of Human Rights. Human Rights Law Journal, 1998, 30. 
gyakorlatával összevetve észszerütlen, ellentétes következtetésre jutna. ${ }^{103}$ Bár jelen ügyben az EJEB és a bíróságok azonos álláspontra helyezkedtek az Egyezmény derogációjával kapcsolatban, ezen az elvi alapon van esély arra, hogy a tagállami bíróság eltérő értelmezése aláássa az EJEB Egyezménnyel kapcsolatos kizárólagos értelmezési jogkörét. ${ }^{104} \mathrm{Ez}$ pedig megnyitja a lehetőségét egy kettős mérlegelési jogkör alkalmazása elött, amelyben egy nem teljesen azonos érvelésü döntésben az állami szervek vélhetően a tagállami bíróság értelmezését fogják elfogadni. ${ }^{105}$ A döntés ugyanakkor egyik nagyon fontos üzenete az Egyezmény 15. cikke értelmezésével kapcsolatban, hogy a különleges intézkedések még kivételes állapotban sem lehetnek diszkriminatívak. ${ }^{106}$

\section{6. Értékelés}

Az Egyezmény 15. cikke kétpólusú rendelkezés, amely a kivételes szabályok alkalmazását a háborúhoz vagy a nemzet létét fenyegető rendkívüli állapothoz köti. Utaltam arra is, hogy amíg az első feltétel viszonylag könnyen értelmezhető, addig a második már jóval nehezebben, így arra az EJEB gyakorlata alapján kaphattunk választ. A Lawless-ügyben az EJEB elöször abban a kérdésben foglalt állást, hogy vajon fennállt-e Írországban a nemzet létét fenyegető rendkívüli állapot. Erre, mint láthattuk, igenlő volt a válasz. ${ }^{107} \mathrm{~A}$ másik kérdés pedig arra irányult, hogy vajon a megtett intézkedések arányban álltak-e a különleges helyzet okozta fenyegetéssel. Az EJEB ezzel összefüggésben is a tagállamnak kedvező megállapítást tett, amikor azt mondta, hogy a megtett intézkedések arányban álltak a felmerült veszéllyel. A 15. cikk egyik pólusa értelmében tehát az EJEB-nek arról kell döntenie, hogy fennáll-e a különleges helyzet, vagyis a tagállami döntés megfelelt-e a körülményeknek. A második pólus alapján az EJEB már az arányosság szem előtt tartásával vizsgálhatja, hogy a megtett intézkedések arányban álltak-e a fennálló különleges helyzettel. Ez az arányosság már a konkrét alapjogsértésre fókuszál, vagyis ezt az EJEB az Egyezmény 15. cikkétöl függetlenül is vizsgálhatná. Ezt a bizonytalanságot tovább erősíti az a tény, hogy az EJEB szinte valamennyi ügyben igazat adott a tagállamoknak és elfogadta, hogy a derogáció alkalmazása szükséges volt, valamint sem az Egyezmény, sem pedig az EJEB gyakorlata nem tesz említést a derogáció időtartamának végéről. $A z$ a tény továbbá, hogy az Egyesült Királyság hosszú évekig élt a 15. cikk adta lehetőséggel, egyre inkább felveti a permanens kivételes állapot kérdését is. ${ }^{108} \mathrm{Az} A$. és mások döntésben ráadásul az EJEB meg is erősítette ezt a feltételezést, amikor a testület leszögezte, hogy a kivételes állapotnak az Egyezmény 15.

103 Az A. és mások kontra Egyesült Királyság ügyben hozott itélet, 179. pont.

104 Elııoт, Mark: The War on Terror, UK style: The Detention and Deportation of Suspected Terrorists. International Journal of Constitutional Law, 2010/1, 131.

105 Sмітн: i. m., 148.

106 Cowell: i. m., 147

107 A Lawless kontra Írország ügyben hozott itélet, 28. pont.

108 GREENE, Alan: Separating Normalcy from Emergency: The Jurisprudence of Article 15 of the European Convention on Human Rights. German Law Journal, 2011/10, 1781-1783. 
cikkének értelmezésében nem kell szükségszerüen „időlegesnek (ideiglenesnek)” lennie. ${ }^{109}$ Amíg azonban az első pólus ilyen mértékben bizonytalan, addig a második pólus az arányosság tesztjével az alapjogi védelem hatékony fegyverének tủnik. Már csak azért is, mert az EJEB is leszögezte, hogy bár a derogációról való döntés politikai jellegű, utóbbi már jogi, ahol a bírósági felülvizsgálat szerepe megkérdőjelezhetetlen az intézkedések jogszerüsége vonatkozásában.

Az Egyezmény 15. cikkének első pólusa tehát azáltal, hogy föként a tagállamok politikai döntésére bízza a derogáció kérdését, egyértelműen az EJEB szerepének adminisztratív jellegére utal és pusztán arra koncentrál, hogy az intézkedések arányosak-e (második pólus). Tény, hogy az EJEB gyakorlata kielégíti a joguralom „igényét”, de pusztán az EJEB e jogkörének fenntartása és esetleges további megőrzése - szigorú arányossági teszt alkalmazása hiányában - azt eredményezné, hogy a normális és a kivételes állapot megkülönböztethetösége egyre inkább elmosódik. ${ }^{110}$ Ezt a hipotézist pedig erősíti, hogy a mérlegelési jogkör alkalmazása során előfordult, hogy az EJEB teret engedett a tagállami visszaéléseknek, ami mindenképpen aggályos fejlemény.

A mérlegelési jogkör doktrínája alapján továbbá az EJEB rugalmasan fogta fel a szuverén államok mozgásterét, igaz az eltérés kérdésében végső soron továbbra is döntő tényező maradt. Alkalmazása kapcsán megállapítható, hogy a tagállamokat széles mérlegelési szabadság illeti meg, egyrészt a különleges helyzet fennállása, másrészt a feltétlenül szükséges intézkedések alkalmazása terén. Viszont az EJEB dönti el, hogy vajon a tagállam túllépte-e a számára biztosított mozgásteret. ${ }^{111}$ Ezzel összefüggésben meg kell ugyanakkor említeni, hogy az eltérés alkalmazása a 15. cikk alapján továbbra is a tagállamok eszköze, amely ügyben az EJEB sokszor megelégszik azzal, hogy egy szükszavú említést tesz a mérlegelési jogkör doktrínájáról anélkül, hogy részletesen bemutatná az érveket, amelyek a konkrét ügy körülményeit figyelembe véve megalapozzák a tényállást. Ez a gyakorlat pedig nyitva hagyja a kérdést, miszerint az EJEB gyakorlatában valóban érvényesül-e a hatékony ellenőrzés. ${ }^{112}$ Amíg tehát a totalitárius rendszerek visszatérésének megelőzése mint az Egyezmény 15. cikkének világos célja teljesült, addig az EJEB hatékony ellenőrzési rendszeréröl mindez egyértelmüen nem állapítható meg.

\section{Abstract}

Emergencies are mostly sudden, and in most cases states need special measures to deal with them. For this reason liberal democracies have standing constitutional or special legal powers to derogate human rights for the sake of order. Those

109 Az A. és mások kontra Egyesült Királyság ügyben hozott ítélet, 178. pont.

110 GREENE: i. m., 1784.

111 GREER, Steven: The Margin of Appreciation: Interpretation and Discretion under the European Convention on Human Rights. Council of Europe Publishing, Strasbourg, 2000, 17.

112 Gross, Oren-Ni AolÁIN, Fionnuala: From Discretion to Scrutiny: Revisiting the Application of the Margin of Appreciation Doctrine in the Context of Article 15 of European Convention on Human Rights. Human Rights Quarterly, 2001/3, 625. 
democracies that do not have such powers, use impromptu ones. It is possible for authoritarian governments to abuse emergency powers in order to stay in power, to derogate human rights and to silence the opposition. Therefore it is essential for a liberal democracy to have strict limits for the duration, circumstance and scope of emergency powers. There are human rights regimes (for example: the European Convention on Human Rights) which have to respect the member states' duty and responsibility in such cases. This article tries to examine this special case law of the European Court of Human Rights. The question is whether a European human rights regime is capable of becoming the guardian of human rights in cases of national emergencies, or the sovereignty of states also means that there is very narrow margin to prove legality above security? 